\title{
Do diatoms in the Swiss Alps reflect the length of ice-cover?
}

\author{
André F. Lotter ${ }^{1}$ and Christian Bigler ${ }^{2,1}$ \\ 1 Geobotanical Institute, University of Bern, Altenbergrain 21, CH-3013 Bern, Switzerland \\ 2 Climate Impacts Research Centre, Abisko Naturvetenskapliga Station, Box 62, \\ SE-98107 Abisko, Sweden
}

Key words: Diatoms, sediment traps, ice-cover, surface sediments, climate change.

\begin{abstract}
Diatom analyses in the water column, sediment traps, surficial sediments as well as in a short sediment core from Hagelseewli (2339 m asl, Swiss Alps) give information about the present-day seasonal cycle of diatom blooms, taphonomic processes in the lake basin and the lake's history. Analyses of surficial sediments show that water depth and thus light and nutrient availability is the most important factor influencing the production and distribution of diatom assemblages in Hagelseewli, and that periphytic diatom valves deposited in the deeper part of the basin originate from the shallow, littoral parts and are transported to the central part by processes such as lateral currents or sediment focussing. The lake is characterised by a very short period (2-3 months) of open water. Water-column and sediment-trap data revealed that planktonic diatoms bloom during and after the ice break-up, whereas mainly periphytic Fragilaria species entered the traps during the ice-covered period. These results suggest that plankton development is strongly inhibited by the ice-cover, with longer periods of ice-cover favouring Fragilaria species in Hagelseewli. The diatom analysis of a short sediment core that includes the last five centuries revealed several changes in the proportion of planktonic diatoms to Fragilaria species. The colder phases of the Little Ice-Age correspond to phases of lower concentration of planktonic diatoms. The highest, statistically significant amount of variance in the downcore diatom data is explained by winter precipitation, which directly influences the length of the ice-cover but inversely influences the light regime.
\end{abstract}

\section{Introduction}

High altitude lakes are subjected to severe environmental conditions. The ice-free, open-water season is short and low water temperatures prevail throughout the year. During most times of the year little light penetrates the opaque snow and ice cover on these lakes. Moreover, lakes above tree-line without glaciers in their catchment are commonly poor in nutrients, usually with clear water conditions that allow high water transparency. Furthermore, in contrast to lowland lakes, remote alpine lakes are among the few aquatic ecosystems that are still widely unaffected by human impact, thus making them less ambiguous indicators for environmental change. 
These extreme environmental conditions can only be tolerated by well-adapted aquatic organisms. Diatom algae are an important group of organisms in high altitude lakes and they are present both as plankton in the water column and as periphyton growing on different substrate types. Periphytic diatoms live in the littoral as well as the illuminated profundal parts of alpine lakes on substrates such as stones, macrophytes, or on the sediment surface. Most diatom studies in the Alps have concentrated on their role as sensitive indicators of anthropogenic acidification in softwater environments (e.g. Arzet et al., 1986; Marchetto and Schmidt, 1993; Niederhauser and Schanz, 1994). Fewer studies have studied the potential of diatoms as indicators of climate change (e.g. Psenner and Schmidt, 1992; Wunsam et al., 1995; Lotter et al., 1997, 1999) or trophic state (Wunsam and Schmidt, 1995; Lotter et al., 1998).

Most lakes above alpine or arctic tree-line are decoupled from the direct atmospheric climate signal (temperature, light) for the major part of the year due to the long ice-cover (Livingstone et al., 1999). This fact hampers the application of organism-specific quantitative inference models and thus a direct reconstruction of past climate change in such high-elevation lakes. Observations of arctic lakes suggest that the amount of planktonic diatoms in relation to periphytic ones, especially Fragilaria species, may give an indication about the length and extent of the ice cover (Smol, 1988; Douglas and Smol, 1999).

In this study we have investigated a lake above tree line in the Swiss Alps to answer the following questions: i) what is the seasonal cycle of diatoms in the water column; ii) where do different diatom taxa live in the lake basin and what taphonomic processes play important roles in the formation of sedimentary assemblages in the deepest part of the basin; iii) what are the important factors regulating diatom communities in these different habitats; and iv) can we infer past climate from diatom assemblages in the lake's sediment?

\section{Methods}

\section{Site}

Hagelseewli $\left(46^{\circ} 40^{\prime} 26^{\prime \prime} \mathrm{N}, 8^{\circ} 02^{\prime} 11^{\prime \prime} \mathrm{E}\right)$ is an elliptically-shaped lake in a north-facing cirque located 300-400 $\mathrm{m}$ above tree line in the Bernese Alps (Switzerland) at an altitude of $2339 \mathrm{~m}$ asl (Fig. 1). The lake has a maximum length of $280 \mathrm{~m}$ and a maximum width of $110 \mathrm{~m}$. The basin has a maximum water depth of $18.5 \mathrm{~m}$ and a surface area of $0.024 \mathrm{~km}^{2}$. The $0.3 \mathrm{~km}^{2}$ catchment of Hagelseewli is composed of scree and alpine meadows and is dominated by a high cliff south of the lake, rising $>40^{\circ}$ above the theoretical horizon of the lake (Ohlendorf et al., in press). This cliff strongly reduces the amount of solar radiation and the lake receives no direct solar radiation between October and February (Goudsmit et al., 2000).

A bathymetric map of the basin was constructed on the basis of 25 echosounding tracks (Fig. 1). Hagelseewli has a simple SW-NE oriented basin morphometry, with a small outflow to the north and only minor surficial inflows along its eastern and western shores.

Daily mean air temperatures can fall below $0{ }^{\circ} \mathrm{C}$ even in summer, and monthly mean temperatures lie below $0^{\circ} \mathrm{C}$ during ca. 6 months of the year. Monthly mean air 


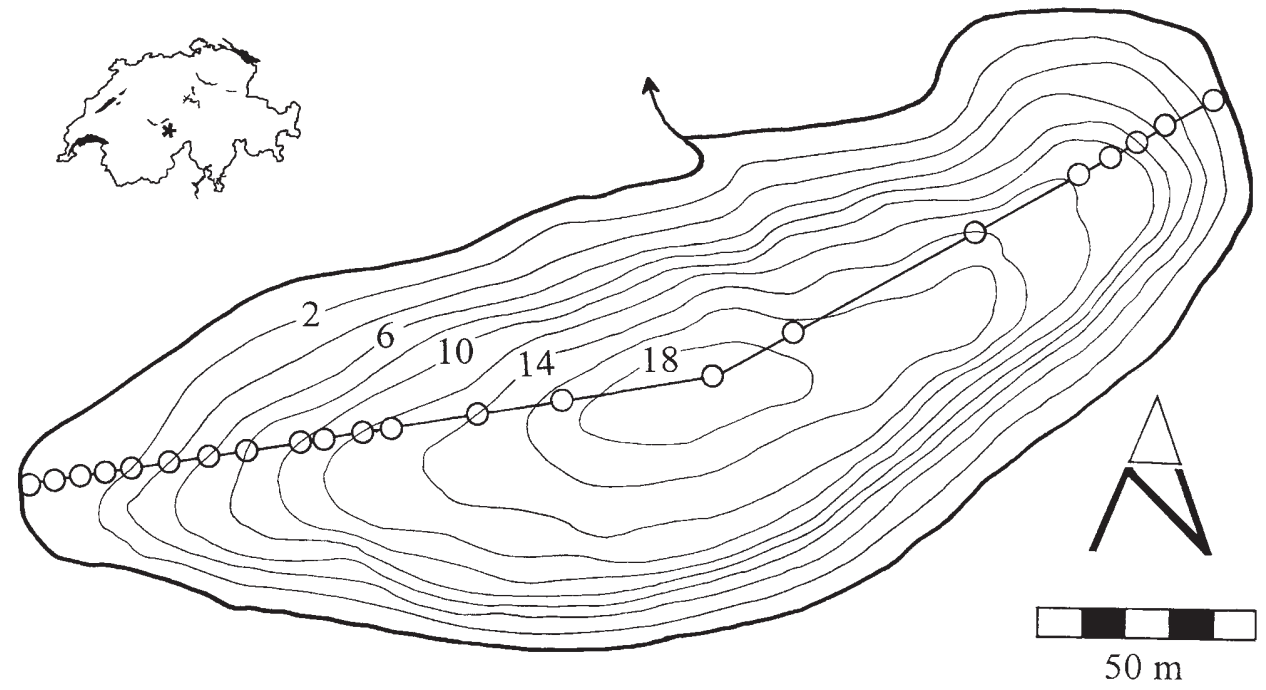

Figure 1. Map of Switzerland indicating the location of Hagelseewli, and bathymetric map of the lake showing 2-m isolines as well as the location of the surface sediment transect with the sampling points

temperatures at Hagelseewli range from $-7.5^{\circ} \mathrm{C}$ in January to $+7.4^{\circ} \mathrm{C}$ in July, with an annual mean of $-0.4^{\circ} \mathrm{C}$ (Ohlendorf et al., in press).

The generally low air temperatures, together with the lack of direct solar radiation, result in the lake being completely or partially ice-covered during most of the year. The lake is only completely ice-free during 2-3 months of the year (July to September). In some years the lake remains frozen during the entire year, as evidenced by aerial photographs taken in mid-August of the years of 1946, 1981, and 1987. Hagelseewli not only thaws very slowly, but also in a very heterogeneous manner. The southern shore below the cliff receives less solar radiation than the northern shore and, therefore, the ice thaws faster in the northern part of the lake. Open water along the northern shore is present at the same time as snow and ice exceeding $1 \mathrm{~m}$ in thickness cover the centre of the lake (Goudsmit et al., 2000; Ohlendorf et al., in press). This transitional phase of partial ice-cover may prevail for some months (e.g., May to July in 1996, 1997, and 1998).

\section{Limnology}

According to the protocols of the EU project MOLAR (Mountain Lake Research) water column physical and chemical parameters were analysed at least monthly in 3-m intervals (Goudsmit et al., 2000). Some limnological characteristics are listed in Table 1. During the stagnation period under the ice, the bottom water of the lake becomes anoxic and phosphorus release from the sediment occurs. Lake oxygenation starts as soon as the northern rim of the lake becomes ice-free (Goudsmit et al., 2000) but during the period of investigation (1996-1998) the lake never completely 
Table 1. Characteristic limnological data of Hagelseewli (averaged values over the whole water column for the period of 1996-1998; $\mathrm{n}=$ number of observations)

Secchi depth
Mean conductivity at $20^{\circ} \mathrm{C}$
Median pH
Median Alkalinity
Median DOC
Median TP
Median $\mathrm{PO}_{4}$
Median Si

$\begin{array}{ll}7-10 \mathrm{~m} & \mathrm{n}=8 \\ 190 \mu \mathrm{S} \mathrm{cm}^{-1} & \mathrm{n}=151 \\ 8.1 & \mathrm{n}=133 \\ 1.8 \mathrm{mmol} \mathrm{L}^{-1} & \mathrm{n}=158 \\ 1.0 \mathrm{mg} \mathrm{C} \mathrm{L}^{-1} & \mathrm{n}=123 \\ 7 \mu \mathrm{g} \mathrm{L}^{-1} & \mathrm{n}=151 \\ 2 \mu \mathrm{g} \mathrm{L}^{-1} & \mathrm{n}=137 \\ 0.6 \mathrm{mg} \mathrm{L}^{-1} & \mathrm{n}=137\end{array}$

mixed (Ohlendorf et al., in press). The surface water temperature does not exceed $8^{\circ} \mathrm{C}$ during the ice-free summer months.

Two sediment traps with a collecting area of $130 \mathrm{~cm}^{2}$ were installed without addition of preservatives at $2 \mathrm{~m}(\operatorname{trap} \mathrm{A})$ and at $17 \mathrm{~m}$ (trap B) water depth in the centre of the lake to assess the particle flux in the water column. Figure 2 shows the length of trap exposure as well as the accumulation rates of the major diatoms in the traps.

The preparation of diatoms from sediment traps largely followed the preparation method for surface sediments. Due to the much smaller sample weight a smaller amount of microspheres was added to reach a similar ratio of diatoms to microspheres (Wolfe, 1997).

The water column was sampled for diatoms by amalgamating seven $250 \mathrm{~mL}$ samples taken at 3-m depth intervals. These samples were centrifuged and diatoms were processed in the same way as for surface sediments and counted at 1000xmagnification and phase contrast using an Olympus BX 50 microscope.

\section{Sediments}

Surface sediment samples $(0-1 \mathrm{~cm})$ were collected in August 1996 along a longitudinal SW to NE transect through the lake at approximately 2-m water depth intervals (Fig. 1). In the deepest part of the basin, a short core of $37 \mathrm{~cm}$ length was collected at a water depth of $18 \mathrm{~m}$. A $6 \mathrm{~cm}$-diameter gravity corer was used to sample the sediments (Renberg, 1991) and the cores were extruded on site in contiguous 5-mm intervals.

For diatom analysis ca $0.4 \mathrm{~g}$ of freeze-dried sediment was heated with $30 \% \mathrm{H}_{2} \mathrm{O}_{2}$ until all organic material was oxidised, then some drops of $10 \% \mathrm{HCl}$ were added to remove carbonates (Battarbee, 1986). Before rinsing the diatom suspensions with distilled water, microspheres were added to determine diatom concentrations (Battarbee and Kneen, 1982), and the suspensions were mounted on slides using Naphrax ${ }^{\circledR}$. At least 400 diatom valves were counted from each sample using a Leitz Dialux 22 microscope at 1000x magnification and phase contrast. Diatom taxonomy followed Krammer and Lange-Bertalot (1986-1991).

Grain-sizes of surface sediments were measured using a Sedigraph 5100 (version 3.05). For technical reasons particles with diameter $>150 \mu \mathrm{m}$ were treated separately and then included in the Sedigraph measurements.

Carbon and nitrogen were measured with a CHNS-Analyzer (Carlo Erba EA 1108). For each sample, $7 \mathrm{mg}$ of freeze-dried sediment was analysed. To determine the 
phosphorus content of the sediments, $25 \mathrm{~mL} \mathrm{HCl}(0.5 \mathrm{~mol}), 5 \mathrm{~mL}$ distilled $\mathrm{H}_{2} \mathrm{O}$ and $250 \mu \mathrm{L} \mathrm{K}_{2} \mathrm{~S}_{2} \mathrm{O}_{8}$ were added to $50 \mathrm{mg}$ freeze-dried sediment. The samples were autoclaved for two hours at $120^{\circ} \mathrm{C}$ and then analysed with a TECHNICON-Autoanalyzer.

The surface diatom assemblages were zoned with the optimal sum of squares partitioning method (Birks and Gordon, 1985) implemented in the computer program ZONE (Lotter and Juggins, 1991). The significant number of diatom zones was assessed by a broken-stick model (Bennett, 1996). Ordination of the diatom and environmental data was carried out with a set of partial redundancy analyses (RDA) using the computer software CANOCO 4 (ter Braak and Smilauer, 1998) and statistical significance of the environmental predictor variables was assessed by 999 restricted Monte Carlo permutations.

\section{Results and discussion}

\section{Sediment trap and water column data}

The results of the diatom analyses of the sediment trap material are presented in Fig. 2. To simplify the graphical presentation, the data were summarised for the major genera. The Fragilaria spp. consisted mainly of $F$. pinnata (var. pinnata), whereas most Achnanthes spp. belonged to A. minutissima. Cymbella spp. included mainly C. minuta. Denticula tenuis, Nitzschia fonticola, Navicula menisculus, and $N$. pupula and a few minor taxa are summarized under "other diatoms".

As expected, large differences in composition and accumulation were observed between the two traps. Light measurements carried out in the water column in September and October 1996 showed that below a water depth of between 11 and $14 \mathrm{~m}$ less than $1 \%$ of the photosynthetically active radiation (PAR) penetrated the water column (Livingstone, unpubl. data). Throughout most of the time, the samples in the upper trap A (2 m water depth) were dominated by Achnanthes minutissima. Given the high light availability in 2 meters water depth (25-33\% PAR during open water season), the transparent trap A provided an ideal artificial substrate for periphytic and tychoplanktonic diatom growth (e.g. A. minutissima) and thus represents rather the periphyton than the planktonic component in the water column. The assemblages in the lower trap B (17 m water depth), however, were dominated by the planktonic Cyclotella comensis most of the time.

Due to the long ice cover with up to $2 \mathrm{~m}$ of snow and ice, it was not possible to assess the timing of diatom blooms during winter and ice-break up at high temporal resolution. Nevertheless, the trap data showed the dynamics during the ice-free period, with closely corresponding relative abundance and accumulation rates (Fig. 2). The blooms of $C$. comensis, as evidenced by high accumulation rates in both traps, took place primarily during the ice-free period in summer. During complete and partial ice-cover, especially during the first two winters, Fragilaria species and other periphytic taxa accumulated in the lower trap B.

Diatom analyses from water samples (Fig. 3) showed a comparable pattern as the sediment traps. Planktonic Cyclotella bloomed mainly during the open-water season in summer, but the onset of the bloom may have taken place already when the lake was still partly ice-covered, when enough light penetrated the ice cover to allow algal 

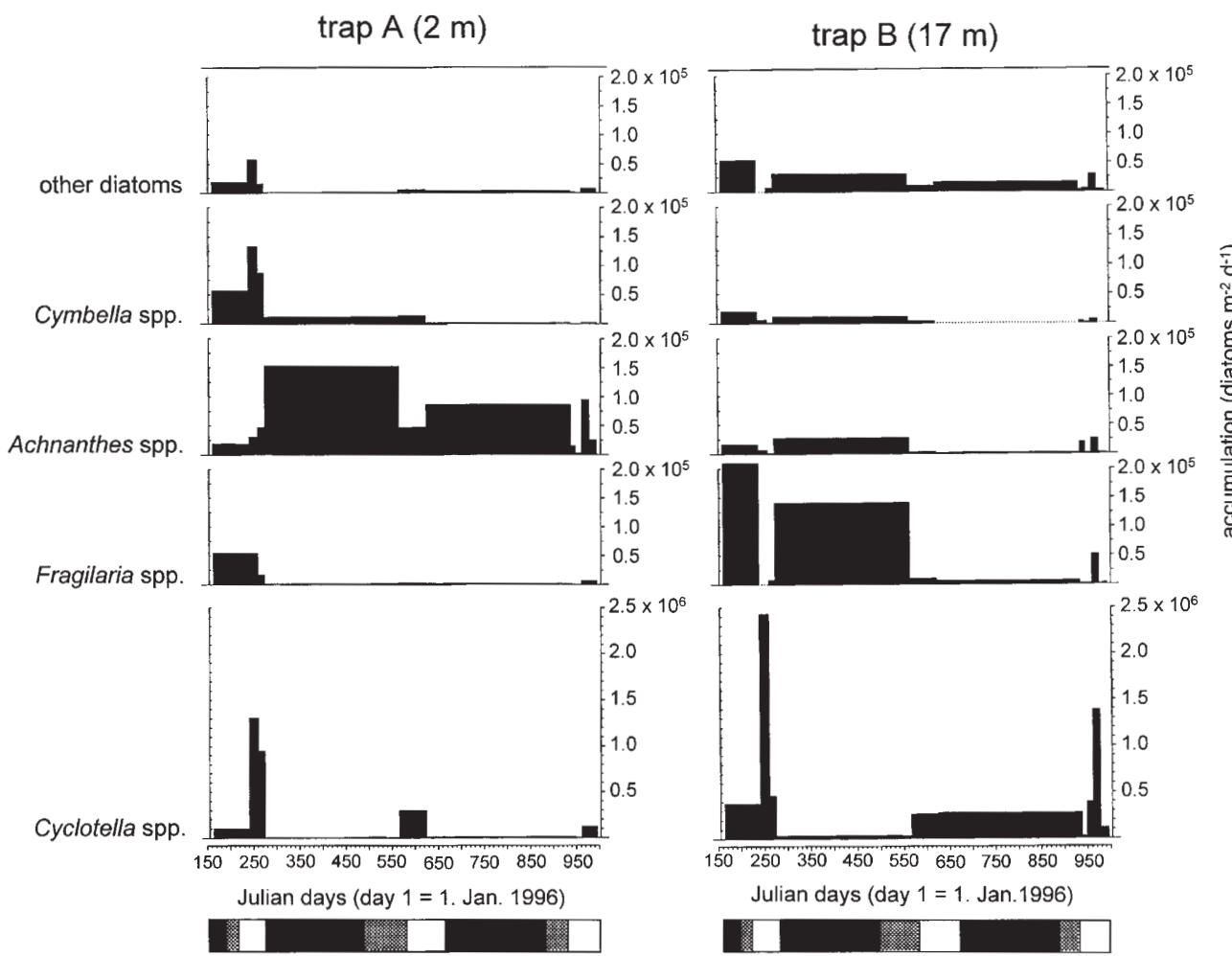

Figure 2. Results from the two sediment traps for the period between 11 June 1996 and 21 September 1998. The time axis is expressed in Julian days, starting on 1 January 1996. The results are expressed as diatom accumulation rates per trap. The bars on the bottom of each graph represent the ice-cover on the lake. Black: totally ice-covered; dotted: marginally open; white: completely open

photosynthesis, as in 1998 (Fig. 3). Periphytic taxa such as Fragilaria species were not an important component in the water column. The other pennate diatoms that were sampled in higher quantities in the water column (e.g. A. minutissima) might be considered as tychoplanktonic taxa. After ice-break up, nutrients such as phosphorus and silica that are released from the sediments during winter anoxia are used up during an extremely short productivity pulse by planktonic algae, with maximum productivity in water depths of between 6 and 9 meters, where the two limiting factors light and phosphorus are optimally available (Ohlendorf et al., in press).

The sediment trap data supports the water column observation of blooms of centric diatoms during open-water conditions (Fig. 2). However, the high accumulation rates of Cyclotella throughout winter 1997/98 are an artefact of the long trap exposure. After the first change of traps in summer 1997, which took place during the onset of the Cyclotella bloom, the traps were then exposed between July 261997 to August 6 1998. The water column samples (Fig. 3) clearly show that the major Cyclotella bloom took place between September and October 1997 and then again 


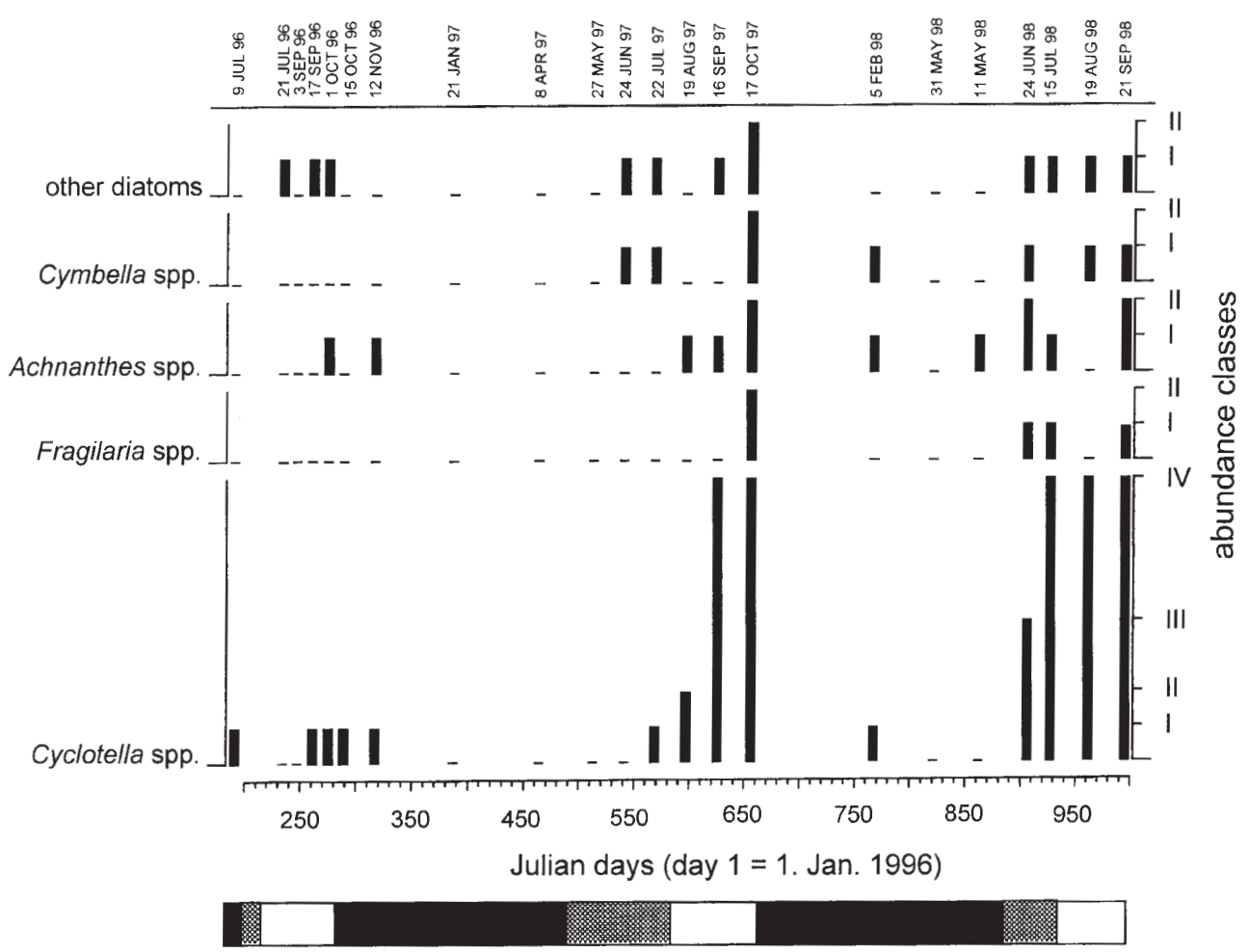

Figure 3. Results of the diatom analyses in the water column of Hagelseewli. Each sample represents an integration of the water column at the deepest point of the lake. For better comparison the diatom counts are expressed in abundance classes. Class I: 0-1 diatoms; class II: 2-20 diatoms; class III: 21-50 diatoms; class IV: $>51$ diatoms per counting unit (one complete row on a cover glass, $18 \mathrm{~mm}$ ). The bar on the bottom of the graph represents the ice-cover on the lake. Black: totally ice-covered; dotted: marginally open; white: completely open

in June and July 1998. Because the traps integrated the particle flux over almost an entire year it is not possible to extract information on the seasonal distribution of diatom blooms for this period.

Fragilaria taxa showed the highest accumulation rates in the sediment traps during the ice-covered period. Models of high arctic lake algal production suggest that the presence of high numbers of small Fragilaria species and low numbers of planktonic diatoms are indicative for a prolonged ice-cover (Smol, 1988; Douglas and Smol, 1999). In Hagelseewli a comparable mechanism seems to take place. As thawing of the ice-cover starts from the northern and northwestern shore, these littoral habitats become first available for colonization by benthic diatoms. According to our observations on the surficial diatom assemblages (Fig. 4) these parts of the lake are mainly colonised by small Fragilaria species such as F. pinnata, F. pseudoconstruens, F. brevistriata. Lateral currents (Goudsmit et al., 2000) and diatom transport by sediment focusing from the shore region to the centre of the lake may have produced the high amount of Fragilaria taxa in the lower but not in 


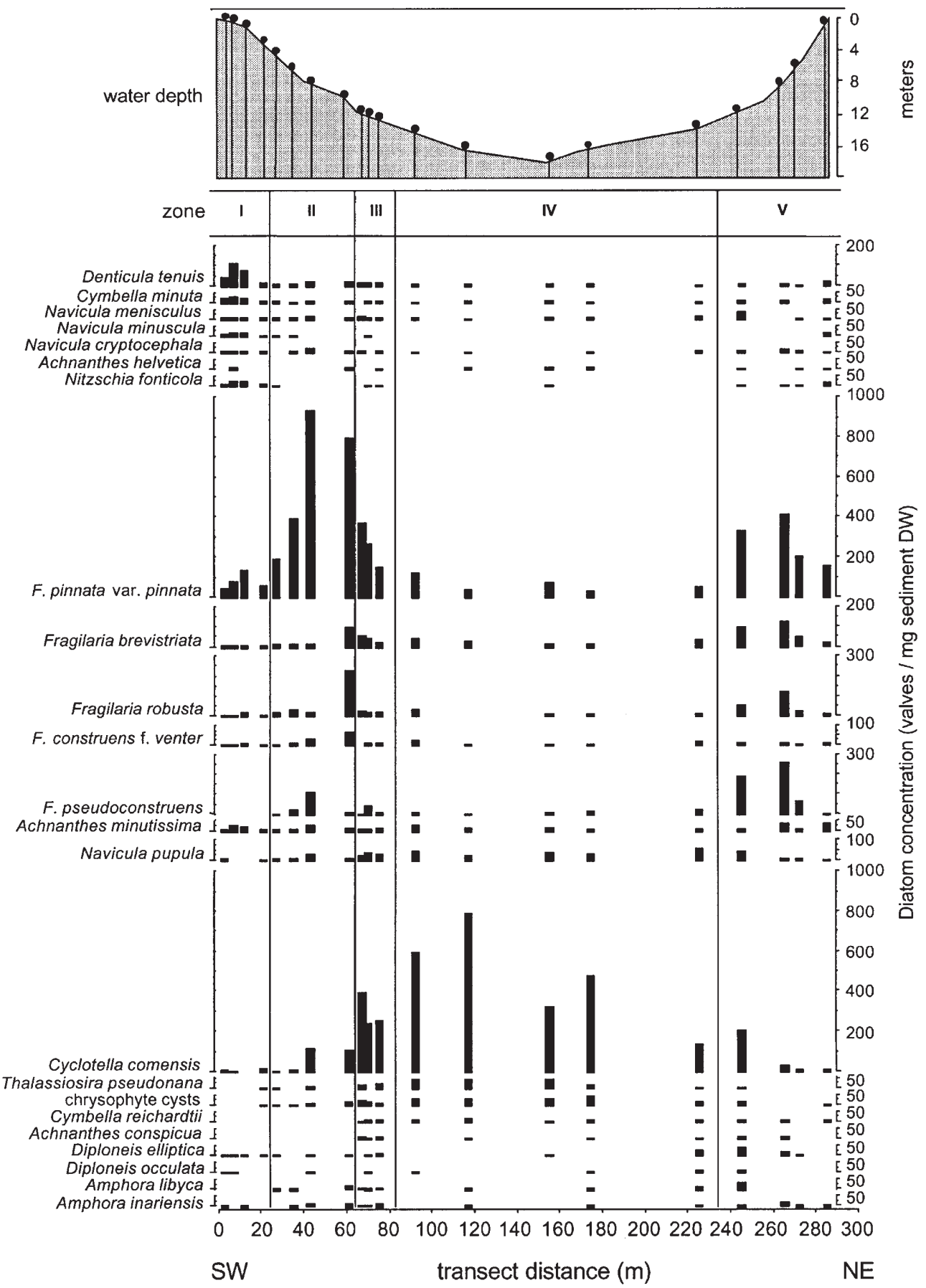

Figure 4. Diatom assemblages in the surficial sediments of Hagelseewli along a SW to NE transect (for location of the samples see bathymetric map in Fig. 1) 
the upper sediment trap (Fig. 2). In autumn, the first ice-layer is transparent, thus changing the conditions for planktonic diatoms drastically. Although there is still enough available light, the ice-cover prevents turbulent mixing that keeps the planktonic diatoms in the water column. According to Stocke's law, the planktonic Cyclotella communities will sink to the lake bottom within a week. The autumn ice cover does, however, not reduce the growing season for epiphytic diatoms unless the first heavy snowfall follows shortly after the freezing of the lake, thus shutting off the light for all life-forms.

The longer the ice-cover, the shorter the growing season for the planktonic diatoms. This effect has also been observed in a Siberian lake where Flower et al. (1998) related the abundance of a centric planktonic diatom to the length of the ice-free season. As soon as marginal thawing in Hagelseewli occurs, the littoral periphytic diatoms have an advantage. Fragilaria species are likely to be $r$-strategists and as such well adapted to changing environmental conditions and may, therefore, be more successful in arctic and alpine lakes than planktonic diatoms at such times.

\section{Surface sediment analyses}

Diatom analyses of surface sediments along the SW to NE transect through Hagelseewli revealed five characteristic assemblage zones (Fig. 4). Zone I includes surface samples taken in water depths between $0.1 \mathrm{~m}$ and $2 \mathrm{~m}$. It is characterised by high concentrations of periphytic taxa such as Denticula tenuis, Cymbella minuta, A. minutissima, Nitzschia fonticola, Navicula minuscula, and also F. pinnata.

Zone II includes diatom assemblages from water depths between $4 \mathrm{~m}$ and $10 \mathrm{~m}$ that are dominated by $F$. pinnata, with elevated occurrences of $F$. robusta and a first slight increase in C. comensis.

Zone III includes samples from water depths between $11.5 \mathrm{~m}$ and $12.5 \mathrm{~m}$ that are characterised by increasing values of $C$. comensis and decreasing abundances of F. pinnata.

The samples included in zone IV come from the deepest part of the basin with water depths between $14 \mathrm{~m}$ and $18 \mathrm{~m}$. Planktonic diatoms such as C. comensis and Thalassiosira pseudonana dominate these assemblages, whereas periphytic diatoms such as Navicula pupula, F. pinnata, as well as chrysophyte cysts, are also present in the deepest part.

The samples in zone $\mathrm{V}$ were taken at the NE end of the lake in water depths between $11.75 \mathrm{~m}$ and $0.2 \mathrm{~m}$. These assemblages are, again, dominated by $F$. pinnata, but other Fragilaria species such as F. pseudoconstruens, F. robusta, F. brevistriata, and $C$. comensis also show high concentrations.

Generally, valves of periphytic pennate diatoms dominate the sediment surface assemblages in the shallow parts down to $2 \mathrm{~m}$ of water, especially at the SW end of Hagelseewli. Fragilaria species, in particular F. pinnata, dominate the surface assemblages in intermediate water depths between $4 \mathrm{~m}$ and $10 \mathrm{~m}$. Valves of planktonic centrics are dominant in the surface assemblages of the deepest part, in water depths of more than $10 \mathrm{~m}$. The ratio of living to dead diatom cells in the surface assemblages shows, for all pennate taxa, the highest amount of living cells at the sites where their concentrations are high. Living cells of planktonic Cyclotella 

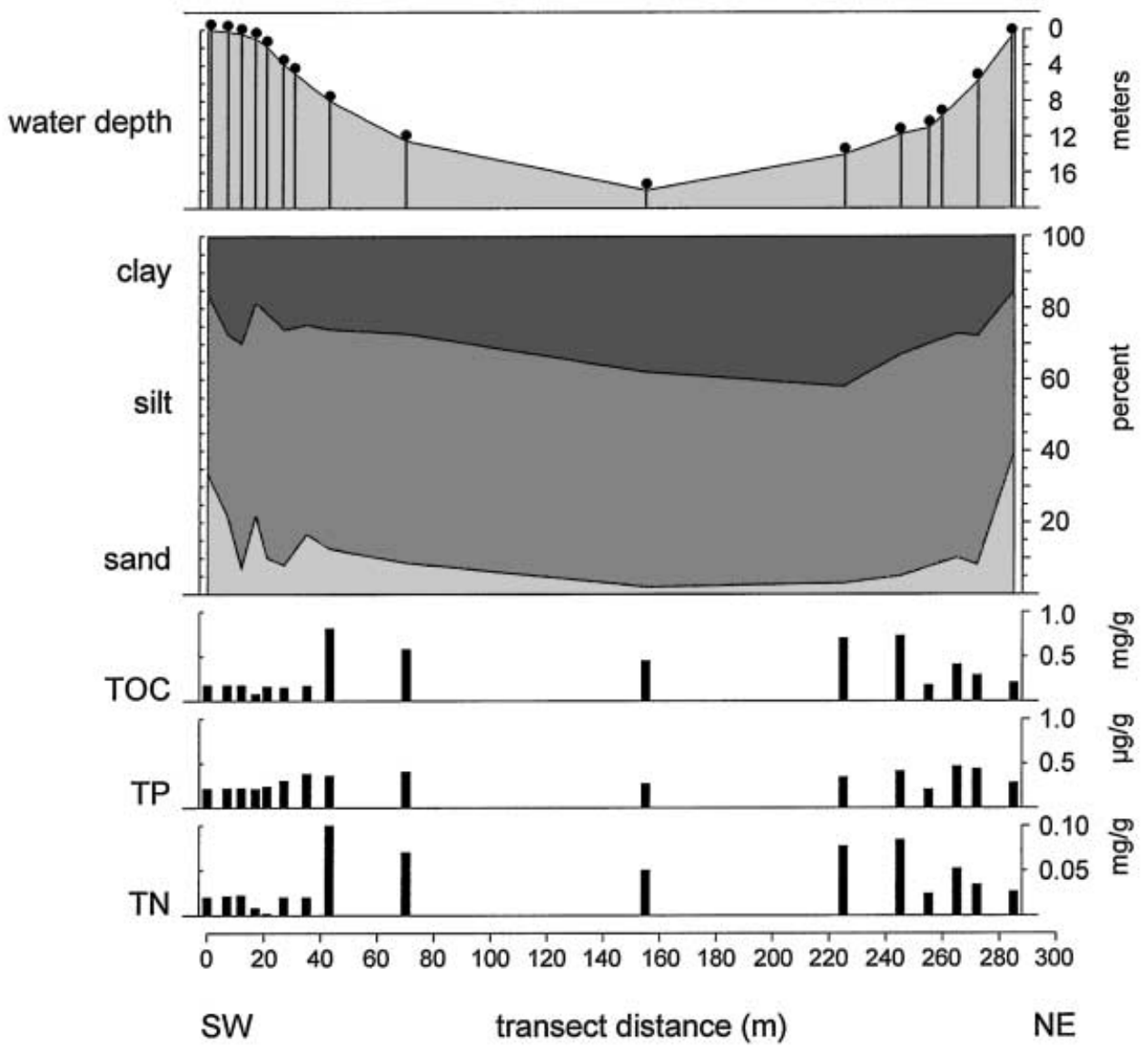

Figure 5. Sedimentological characteristics of the surficial sediment samples along the SW to NE transect (for location of the samples see Fig. 1)

reached their highest ratios in samples from water depths of between $8 \mathrm{~m}$ and $10 \mathrm{~m}$. The ratios were slightly lower in the shallower part of the lake and considerably lower in the deep part (Bigler, 1998).

Figure 5 shows the sedimentological results of the surface sediment analyses. Grain-size distribution shows a clear zonation of the surficial sediments. A higher amount of sand ( $30 \%$; grain-size $>63 \mu \mathrm{m})$ was found close to the shores, then fell below $10 \%$ in water-depths higher than $10 \mathrm{~m}$ and reached minimum values of $2 \%$ in the deepest part of the basin. The silt fraction $(2-63 \mu \mathrm{m})$ showed stable values of between $55-60 \%$ along the transect and declined to $45-50 \%$ towards the shores. The clay fraction $(<2 \mu \mathrm{m})$ had its highest values in water-depths between $14 \mathrm{~m}$ and $18 \mathrm{~m}$.

Geochemical analyses showed that TIC (total inorganic carbon) was below detection limit, which is due to dissolution of calcite at the water/sediment interface (Ohlendorf et al., in press). The surficial sediments in water depths of more than $10 \mathrm{~m}$ were rich in TOC (total organic carbon), whereas the TOC content towards the 
Table 2. Variance in the surface sediment diatom assemblages explained by the environmental variables in a (partial) RDA when used as sole predictor (marginal effects) and when the influence of the other predictors is partialled out (unique effects)

\begin{tabular}{llllll}
\hline Environmental variable & \multicolumn{2}{l}{ Marginal effects } & & \multicolumn{2}{l}{ Unique effects } \\
\cline { 2 - 3 } \cline { 5 - 6 } & $\%$ & & & $\%$ & $\mathrm{p}$ \\
\hline Water depth & 46.8 & $0.001^{\text {a }}$ & & 33.4 & $0.001^{\text {a }}$ \\
TOC content of sediment & 29.7 & $0.001^{\text {a }}$ & & 4.8 & 0.513 \\
Sand content of sediment & 14.0 & 0.208 & & 8.9 & 0.093 \\
Clay content of sediment & 12.6 & 0.247 & & 2.7 & 0.964 \\
Distance along transect & 13.1 & 0.667 & & 20.3 & 0.071
\end{tabular}

a Statistically significant at $\mathrm{p} \leq 0.05$, as assessed by 999 restricted Monte Carlo permutations.

shores was lower due to the presence of coarser minerogenic particles. The concentrations of TN (total nitrogen) followed the TOC curve closely, whereas the TP (total phosphorus) concentration did not show much change along the transect.

The zonation of the modern diatom assemblages exhibits a typical succession from littoral periphytic diatoms (mainly Fragilaria species) to pelagic planktonic communities (mainly C. comensis). According to a partial RDA, water depth is the most important explanatory variable for the distribution of the modern diatom assemblages. It is the only environmental variable that explains a significant amount of the variance in the surface diatom assemblages when the effect of substrate composition and location along the transect are statistically accounted for (Table 2). The variance explained by environmental parameters such as water depth, TOC, $\mathrm{TP}$, and distance along the transect is shown in Table 2. Marginal effects explain the amount of variance when each environmental parameter is used as sole explanatory variable. Here, not only the impact of the sole predictor but also other parameters that are correlated with it are influencing the result. These marginal variances are, therefore, generally an overestimate of the amount of variance explained by each environmental parameter. By partialling out the effects of other environmental variables, the unique effects can be assessed (Table 2).

The SW to NE light-gradient (i.e. distance along the transect) also represents a gradient of length of the open water period and, most probably, a water temperature gradient. Light availability explains a large but statistically insignificant part $(20.3 \%)$ of the variance, indicating that the better light availability at the southwestern part of the basin has an influence on the diatom assemblages. Besides this gradient in light availability, the major differences in assemblages between the SW and the NE shore are mainly due to the lake morphometry: in the SW part, more littoral habitats are available which favour the periphytic diatoms (zone I, see Fig. 4), whereas the steeper slope at the NE end of the lake produces a steeper water-depth gradient with less shallow and flat sediment surfaces as well as different substrate types (see e.g. Cox, 1988). Furthermore, the sampling density at the SW end is higher, covering more water depths. An alternative explanation of the asymmetrical distribution of the surface sediment diatom assemblages may be the influence of ground water inflow, which is higher at the SW end of the lake, thus enhancing benthic diatom growth (e.g. Dean and Bradbury, 1997). 


\section{Sediment core}

The 37-cm-long sediment core taken in the deepest part of the lake dates back to ca. A.D. 1100 (Lotter et al., submitted.). Only the upper $20 \mathrm{~cm}$ that date back to the mid- $16^{\text {th }}$ century are shown in Figure 6 . According to sedimentological and geomagnetic analyses (Lotter et al., in press) the sediment between 6 and $7 \mathrm{~cm}$ does not reflect the continuous accumulation in the basin, but was deposited as a result of a brief, single event (turbidite or slump).

The core is characterised by an alternation between planktonic taxa (mainly Cyclotella comensis) and periphytic Fragilaria species such as F. pinnata, F. parasitica and F. construens var. venter (Figs. 6 and 7). Other periphytic taxa (e.g. A. minutissima, N. seminulum, C. minuta, and Diploneis elliptica) do not play an important role. The diatom accumulation rates, however, show that this alternation in relative abundances is mainly caused by the changing concentrations of planktonic diatoms (Fig. 7).

The changes in the life-form composition of the diatom assemblages in the sediment of Hagelseewli are likely to reflect changes in the length of ice-cover, as evidenced by the modern water-column data. Phases with low relative and absolute abundances of planktonic diatoms, as well as elevated relative numbers of Fragilaria species, occur during the first two thirds of the $20^{\text {th }}$ century, and, with short interruptions, between the mid- $17^{\text {th }}$ and mid- $19^{\text {th }}$ centuries (see Figs. 6 and 7). Sediment chronology for the Hagelseewli record is based on ${ }^{137} \mathrm{Cs}$ and ${ }^{210} \mathrm{~Pb}$ dating and is, therefore, only reliable for the last ca. 150 years. Ages older than 1820 A.D. have been extrapolated using a constant sedimentation rate (Lotter et al., in press). Assuming a correct chronology for the Hagelseewli record, the older phase of higher Fragilaria abundance before 1850 A. D. is contemporaneous with the Little Ice Age. Despite the chronological uncertainties in the older part of the Hagelseewli record, a comparison of the diatom data with available historical climate data such as the graduated indices for monthly or seasonal Swiss temperatures and precipitation by Pfister (1992) was attempted. These indices are mainly based on observations from lowland Switzerland. Livingstone and Lotter (1998) and Livingstone et al. (1999) showed that instrumental temperature time-series are very homogenous for the whole of the Swiss Plateau and that the summer temperatures may be extrapolated to sites at higher elevation in the Alps by use of lapse rates. Moreover, Livingstone (1997) showed that mean April air temperature correlated best with the ice break-up dates of several central Alpine lakes. Averaged mean spring temperatures between ca. the mid- $16^{\text {th }}$ century and the late 1930 s, as estimated by Pfister's (1992) indices, are generally below today's averages so that a late ice breakup could be expected for this period. Although the high amounts of Fragilaria between ca. 1860 and the late 1960s do not match the available temperature data, the spring and autumn precipitation was higher during this period. Spring and autumn precipitation at this elevation fall as snow and may thus prolong the duration of ice-cover on the lake. This, in turn, would hamper the development of planktonic diatoms. The significance of unique effects explaining the variance in the diatom data (Table 3) also points to the importance of precipitation rather than temperature for the diatom assemblages. Besides a strong temporal trend, winter precipitation explains the largest statistically significant amount of variance in the 


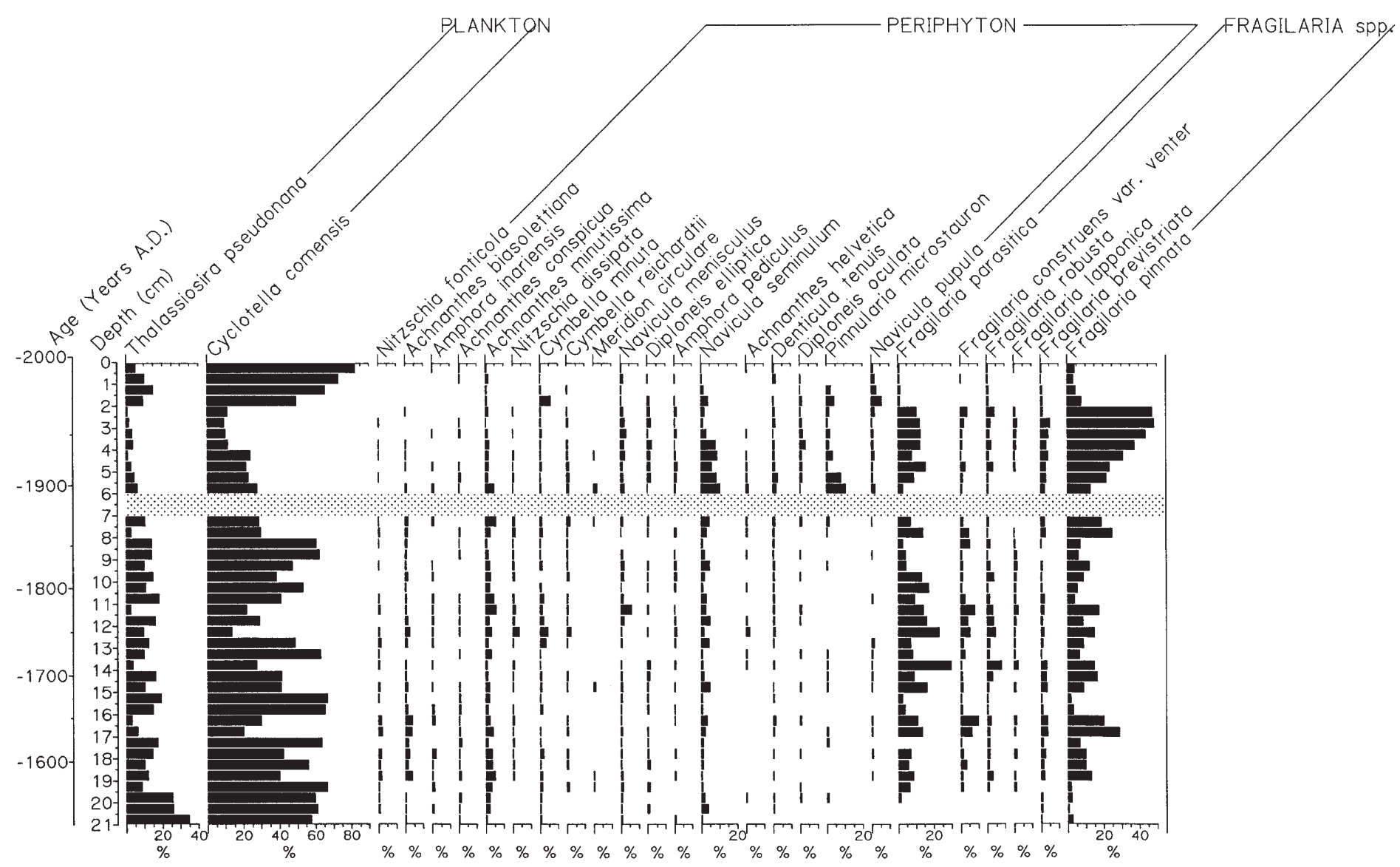

Figure 6. Diatom percentage diagram of the topmost $20 \mathrm{~cm}$ of core Hagelseewli HAG96-1 taken in the deepest part of the lake (18.5 m), analysed in contiguous $0.5 \mathrm{~cm}$ intervals. The shaded area between 6 and $7 \mathrm{~cm}$ represents sediment originating from a brief, single event 


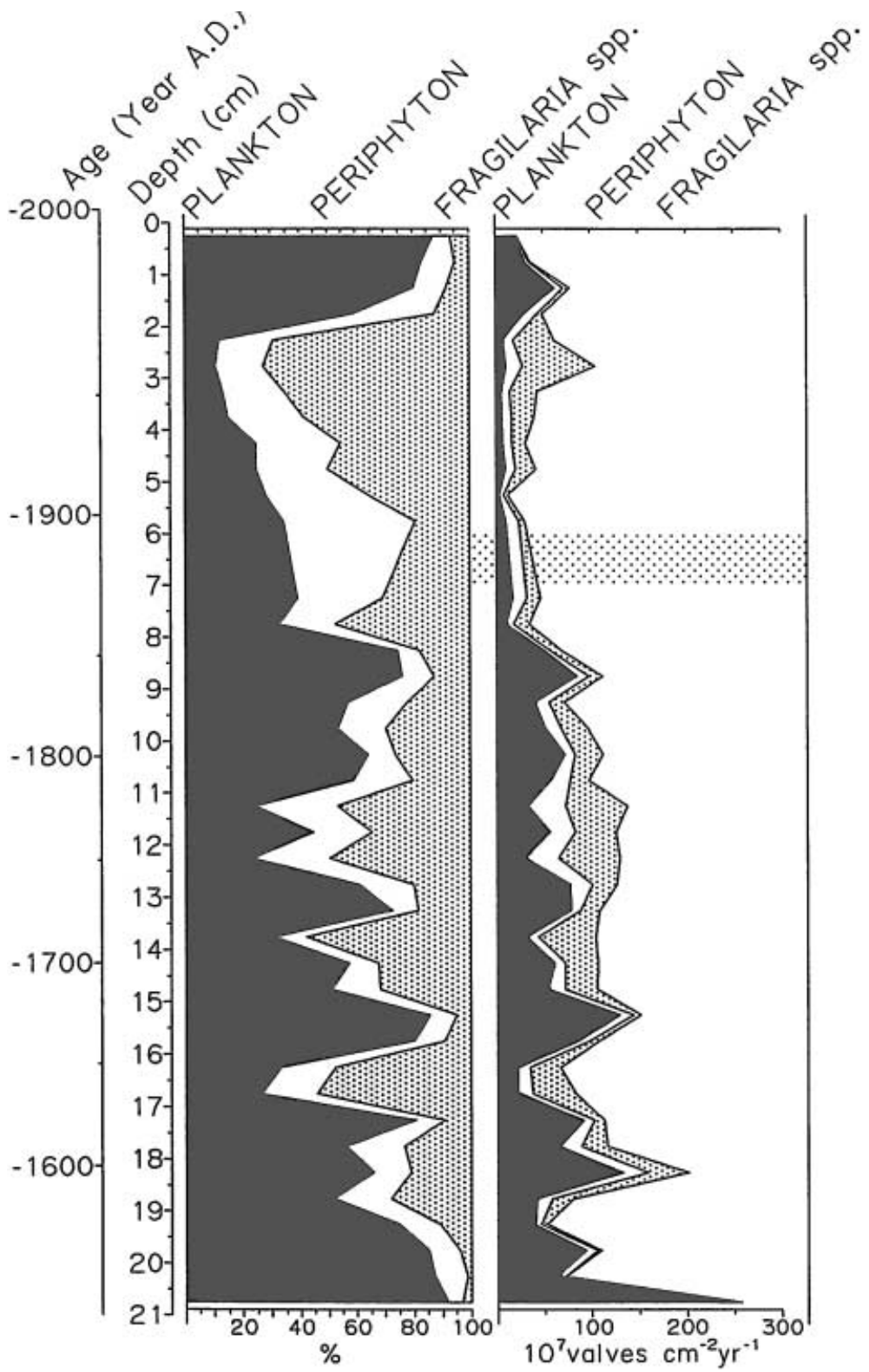

Figure 7. Grouping of diatoms according to their life-form on the basis of diatom percentages and diatom accumulation rates. The shaded area between 6 and $7 \mathrm{~cm}$ represents sediment originating from a brief, single event 
Table 3. Variance in the downcore sediment diatom assemblages explained by sediment age and the seasonal climate indices for the period between 1989 and 1526 (Pfister, 1992) in a (partial) RDA when used as sole predictor (marginal effects) and when the influence of the other predictors is partialled out (unique effects). Indices representing the years encompassed in the sediment samples were averaged

\begin{tabular}{|c|c|c|c|c|c|c|}
\hline \multirow{2}{*}{$\begin{array}{l}\text { Covariable } \\
\text { Climate Variable }\end{array}$} & \multicolumn{2}{|c|}{$\begin{array}{l}\text { Marginal effect } \\
\text { none }\end{array}$} & \multicolumn{2}{|c|}{$\begin{array}{l}\text { Marginal effect } \\
\text { sediment age }\end{array}$} & \multicolumn{2}{|c|}{$\begin{array}{l}\text { Unique effect } \\
\text { all }\end{array}$} \\
\hline & $\%$ & $\mathrm{p}$ & $\%$ & $\mathrm{p}$ & $\%$ & $\mathrm{p}$ \\
\hline Sediment age & 17.0 & $0.001^{\mathrm{a}}$ & & & 21.7 & $0.001^{\circ}$ \\
\hline Winter temperature & 5.4 & 0.301 & 3.4 & 0.201 & 3.0 & 0.310 \\
\hline Spring temperature & 5.1 & 0.235 & 2.8 & 0.441 & 2.6 & 0.381 \\
\hline Summer temperature & 1.3 & 0.864 & 1.3 & 0.904 & 2.9 & 0.486 \\
\hline Autumn temperature & 4.8 & 0.439 & 4.4 & 0.209 & 4.6 & 0.133 \\
\hline Winter precipitation & 3.6 & 0.499 & 5.6 & 0.107 & 8.2 & $0.026^{\circ}$ \\
\hline Spring precipitation & 4.2 & 0.236 & 6.9 & 0.087 & 5.3 & 0.178 \\
\hline Summer precipitation & 1.6 & 0.910 & 2.0 & 0.666 & 5.3 & 0.224 \\
\hline Autumn precipitation & 1.4 & 0.747 & 2.4 & 0.458 & 1.7 & 0.764 \\
\hline
\end{tabular}

a Statistically significant at $\mathrm{p} \leq 0.05$, as assessed by 999 restricted Monte Carlo permutations.

diatom data when the effects of time and the other climatic variables such as seasonal temperature and precipitation are partialled out. The amount of snow accumulation on the ice has a strong influence on the length of ice-cover on Hagelseewli.

\section{Conclusions}

Our investigations in the water column and the sediments of Hagelseewli in the Swiss Alps revealed several results that are relevant for diatom investigations in alpine and arctic lakes:

i) The seasonal cycle of diatom blooms in the water column depends largely on the timing of the ice out. The thawing of the ice increases the light availability and together with the abundantly available nutrients that are mobilized from the sediments during the ice-covered period triggers a productivity pulse. Depending on light-availability, the onset of planktonic diatom blooms may already occur when the lake is still partially ice-covered.

ii) Diatom assemblages in the surficial sediments of Hagelseewli reflect a strong influence of water depth. In this clearwater lake, water depth represents a gradient of light-availability. Down to a water depth of 8-10 $\mathrm{m}$, the assemblages are dominated by periphytic diatoms, especially Fragilaria species, whereas in water depths $>10 \mathrm{~m}$ valves of planktonic taxa (Cyclotella comensis) predominate in the surficial assemblages.

iii) As the lake thaws from its shores towards the centre, littoral habitats become first ice-free and thus available for periphytic diatom growth. Lateral currents and sediment focusing may transport periphytic diatoms, mainly Fragilaria species, to the deepest part of the basin, as evidenced by sediment trap data. The longer the opaque snow and ice-cover remain in the centre of the lake, the 
less plankton can develop in the water column. According to these results, the ratio between planktonic diatoms and periphytic Fragilaria species gives some information on the length of ice-cover on alpine and arctic lakes.

iv) A short sediment core from the deepest part of Hagelseewli shows marked changes in the ratio of planktonic to periphytic diatoms. Phases with higher amounts of Fragilaria species are contemporaneous with the Little Ice Age in the Alps and thus suggest a longer ice-cover on the lake during this cold phase.

v) Winter precipitation is the strongest, statistically significant environmental predictor of the downcore diatom data and supports our ice-cover hypothesis because winter precipitation (snow) effectively lengthens the period of ice cover.

\section{ACKNOWLEDGEMENTS}

We should like to thank the following persons for their help during field and lab work: G. Lemcke, C. Meile, D.M. Livingstone, D. Siegrist, M. Sturm, I. R. Walker, M. Wehrli, and A. Zwyssig. D. M. Livingstone generously provided unpublished PAR data. The manuscript was prepared during a stay of the first author at Abisko Naturvetenskapliga Station (ANS); the CIRC group and ANS are acknowledged for their hospitality. R.I. Hall, J.P. Bradbury, and J.P. Smol made valuable comments on an earlier version of the manuscript. This research was supported by the EC Environment and Climate Research Programme (Project MOLAR, contract: ENV4-CT95-008) and the Swiss Priority Programme Environment (project 5001-044600).

\section{REFERENCES}

Arzet, K., C. Steinberg, R. Psenner and N. Schulz, 1986. Diatom distribution and diatom inferred $\mathrm{pH}$ in the sediment of four alpine lakes. Hydrobiologia 143: 247-254.

Battarbee, R.W., 1986. Diatom analysis. In: B.E. Berglund (Editor), Handbook of Holocene Palaeoecology and Palaeohydrology. J.Wiley \& Sons, Chichester, pp. 527-570.

Battarbee, R.W. and M.J. Kneen, 1982. The use of electronically counted microspheres in absolute diatom ananalysis. Limnology and Oceanography 27: 184-188.

Bennett, K.D., 1996. Determination of the number of zones in a biostratigraphical sequence. New Phytologist 132: 155-170.

Bigler, C., 1998. Verbreitung von Diatomeen im Oberflächensediment eines alpinen Sees im Berner Oberland (Hagelseewli 2339 m ü. M.). Diplomarbeit, Universität Bern, 79 pp.

Birks, H.J.B. and A.D. Gordon, 1985. Numerical Methods in Quaternary Pollen Analysis. Academic Press, London, 289 pp.

Cox, E.J., 1988. Has the role of the substratum been underestimated for algal distribution patterns in freshwater ecosystems? Biofouling 1: 49-63.

Dean, W.E. and J.P. Bradbury, 1997. Transects of organic carbon, calcium carbonate and diatoms in surface sediments of Williams and Shingobee lakes. In: T.C. Winter (Editor), Hydrological and biogeochemical research in the Shingobee river headwater area, north-central Minnesota. Water-Resources Investigations Report 96-4215. U.S. Geological Survey, Denver, Colorado, pp. 117-129.

Douglas, M.S.V. and J.P. Smol, 1999. Freshwater diatoms as indicators of environmental change in the High Arctic. In: E.F. Stoermer and J.P. Smol (Editors), The diatoms: application for the environmental and earth sciences. Cambridge University press, Cambridge, pp. 227-244.

Flower, R.J., S.P. Ozornina, A. Kuzmina and F.E. Round, 1998. Pliocaenicus taxa in modern and fossil material mainly from eastern Russia. Diatom Research 13: 39-62.

Goudsmit, G.-H., G. Lemcke, D.M. Livingstone, A.F. Lotter, B. Müller and M. Sturm, 2000. Hagelseewli: a fascinating high mountain lake - suitable for palaeoclimatic studies? Verhandlungen Internationale Vereinigung für Limnologie, 27: in press

Krammer, K. and H. Lange-Bertalot, 1986-1991. Bacillariophyceae. Süsswasserflora von Mitteleuropa, 2/1-2/4. G. Fischer Verlag, Stuttgart. 
Livingstone, D.M., 1997. Break-up dates of Alpine lakes as proxy data for local and regional mean surface air temperatures. Climatic Change 37: 407-439.

Livingstone, D.M. and A.F. Lotter, 1998. The relationship between air and water temperatures in lakes of the Swiss Plateau: a case study with palaeolimnological implications. Journal of Paleolimnology 19: 181-198.

Livingstone, D.M., A.F. Lotter and I.R. Walker, 1999. The decrease in summer surface water temperature with altitude in Swiss Alpine lakes: a comparison with air temperature lapse rates. Arctic, Antarctic and Alpine Research 31: 341-352.

Lotter, A.F., H.J.B. Birks, W. Hofmann and A. Marchetto, 1997. Modern diatom, cladocera, chironomid, and chrysophyte cyst assemblageges as quantitative indicators for the reconstruction of past environmental conditions in the Alps. I. Climate. Journal of Paleolimnology 18: 395-420.

Lotter, A.F., H.J.B. Birks, W. Hofmann and A. Marchetto, 1998. Modern diatom, cladocera, chironomid, and chrysophyte cyst assemblageges as quantitative indicators for the reconstruction of past environmental conditions in the Alps. II. Nutrients. Journal of Paleolimnology 19: 443-463.

Lotter, A.F., R. Pienitz and R. Schmidt, 1999. Diatoms as indicators of environmental change near Arctic and Alpine treeline. In: E.F. Stoermer and J.P. Smol (Editors), The diatoms: application for the environmental and earth sciences. Cambridge University press, Cambridge, pp. 205-226.

Lotter, A.F. and S. Juggins, 1991. POLPROF, TRAN and ZONE: programs for plotting, editing and zoning pollen and diatom data. INQUA-Subcommission fot the study of the Holocene Working Group on Data-Handling Methods, Newsletter 6: 4-6.

Lotter, A.F., P. Appleby, J.A. Dearing, J.-A. Grytnes, W. Hofmann, C. Kamenik, A. Lami, D.M. Livingstone, C. Ohlendorf, N. Rose, M. Sturm and R. Thompson, in press. The record of the last 200 years in the sediments of Hagelseewli (2339 m asl), a high-elevation lake in the Swiss Alps. Journal of Paleolimnology.

Marchetto, A. and R. Schmidt, 1993. A regional calibration data set to infer lakewater $\mathrm{pH}$ from sediment diatom assemblages in alpine lakes. Memorie dell'Istituto Italiano di Idrobiologia 51: $115-125$.

Niederhauser, P. and F. Schanz, 1994. Comparison of diatom communities in remote high-mountain lakes using index B and cluster analysis. Hydrobiologia 274: 115-120.

Ohlendorf, C., C. Bigler, G.H. Goudsmit, G. Lemcke, D.M. Livingstone, A.F. Lotter, B. Müller and M. Sturm, in press. Causes and effects of long periods of ice cover on a remote high Alpine lake. Journal of Limnology.

Pfister, C., 1992. Monthly temperature and precipitation in central Europe 1525-1979: quantifying documentary evidence on weather and its effects. In: R.S. Bradley and P.D. Jones (Editors), Climate since A.D. 1500. Routledge, London, pp. 118-142.

Psenner, R. and R. Schmidt, 1992. Climate-driven $\mathrm{pH}$ control of remote alpine lakes and effects of acid deposition. Nature 356: 781-783.

Renberg, I., 1991. The HON-Kajak sediment corer. Journal of Paleolimnology 6: 167-170.

Smol, J.P., 1988. Paleoclimate proxy from freshwater arctic diatoms. Verhandlungen Internationale Vereinigung für Limnologie 23: 837-844.

ter Braak, C.J.F. and P. Smilauer, 1998. CANOCO reference manual and user's guide for Canoco for Windows. Software for Canonical Community Ordination (version 4). Microcomputer Power, $352 \mathrm{pp}$.

Wolfe, A.P., 1997. On diatom concentrations in lake sediments: results from an inter-laboratory comparison and other tests performed on a uniform sample. Journal of Paleolimnology 18: 261-268.

Wunsam, S. and R. Schmidt, 1995. A diatom-phosphorus transfer function for alpine and prealpine lakes. Memorie dell'Istituto Italiano di Idrobiologia 53: 85-99.

Wunsam, S., R. Schmidt and R. Klee, 1995. Cyclotella-taxa (Bacillariophyceae) in lakes of the Alpine region and their relationship to environmental variables. Aquatic Sciences 57: 360-386.

Received 12 September 1999;

revised manuscript accepted 25 May 2000. 